\title{
Kajian Kapasitas Adaptasi Masyarakat Pesisir Pekalongan terhadap Kerentanan Banjir Rob
}

\author{
Hilma Qoniana Purifyningtyas ${ }^{1}$ \\ PT Stadia Reka, Semarang, Indonesia
}

\section{Holi Bina Wijaya}

Departemen Perencanaan Wilayah dan Kota

Fakultas Teknik, Universitas Diponegoro, Semarang, Indonesia

Artikel Masuk : 4 April 2016

Artikel Diterima : 17 Mei 2016

Tersedia Online : 31 Agustus 2016

\begin{abstract}
Abstrak: Kota Pekalongan adalah daerah pesisir yang rentan terhadap banjir rob. Ada delapan desa yang senantiasa tergenang banjir rob, termasuk Desa Pabean dan Desa Bandengan. Kapasitas adaptif masyarakat perlu ditingkatkan untuk menghadapi banjir rob. Tujuan penelitian untuk menilai kapasitas adaptasi masyarakat pesisir Pekalongan terhadap kerentanan banjir pasang. Penelitian menggunakan metode kuantitatif dengan analisis skoring dan statistik deskriptif untuk mensintesis hasil analisis. Kapasitas adaptif dinilai pada tingkat individu, masyarakat, dan kota. Analisis juga didasarkan pada aspek fisik, sosial dan ekonomi. Hasil analisis menunjukkan bahwa pada tingkat individu, tingkat adaptasi masyarakat rendah. Hal ini disebabkan oleh rendahnya kemampuan masyarakat untuk memperbaiki rumah. Tingkat kapasitas adaptasi juga dipengaruhi oleh tingkat tingkat pendidikan dan pendapatan. Di tingkat masyarakat, tingkat kapasitas adaptif ditentukan oleh kemampuan masyarakat untuk meningkatkan infrastruktur. Tingkat kapasitas adaptasi juga ditentukan oleh keberadaan organisasi dan kemampuan untuk mengumpulkan dana.Tingkat kapasitas adaptasi di tingkat masyarakat adalah sedang. Di tingkat kota, pemerintah mampu beradaptasi dengan menyediakan teknologi dan kelembagaan. Masyarakat perlu untuk meningkatkan kapasitas adaptif dengan meningkatkan kemampuan ekonomi, selain mengoptimalkan kinerja organisasi pemerintah dan nonpemerintah.
\end{abstract}

Kata Kunci: derajat kerentanan, kapasitas adaptasi, pesisir Pekalongan

Abstract: Pekalongan City is a coastal city vulnerable to tidal flood. There are eight tidal flood prone villages including Pabean and Bandengan villages. Community adaptive capacity requires improvements to dealing with it. This study aimed to assess the adaptive capacity of the coastal communities in Pekalongan against the tidal flood vulnerability. The study employed quantitative method with scoring and descriptive statistical analyses for synthesizing the results. The adaptive capacity was assessed at the levels of individuals, communities and cities. It also measured physical, social, and economic aspects. The results showed that at the individual level the adaptive capacity level of communities in both villages

\footnotetext{
${ }^{1}$ Korespondensi Penulis: PT. Stadia Reka, Semarang, Indonesia

Email: hilma.qoniana.p@gmail.com
} 


\section{2}

Kajian Kapasitas Adaptasi Masyarakat Pesisir Pekalongan terhadap Kerentanan Banjir Rob

was low. It was caused by the low ability of the communities to fixing their houses. It was also influenced by their education and income levels. At the community level, the level of adaptive capacity was determined by the ability of communities to improve infrastructure. It was also determined by the existence of the organization and their ability to raise funds. At this level, the level of adaptive capacity was moderate. At the city level, the government was able to adapt by providing technology and institution. The community needs to increase the adaptive capacity by improving the ability of the economyin addition tooptimizing the performance of government and non-government organizations.

Keywords: level of vulnerability, adaptive capacity, Pekalongan coastal area

\section{Pendahuluan}

Salah satu daerah yang memiliki kerentanan terhadap bencana adalah daerah pesisir. Bencana yang sering terjadi di daerah pesisir adalah banjir rob. Rob adalah kejadian atau fenomena alam dimana air laut masuk ke wilayah daratan pada waktu permukaan air laut mengalami pasang. Intrusi air laut tersebut dapat melalui sungai, saluran drainase atau aliran bawah tanah (Noson, 2002). Data PSDA Kota Pekalongan tahun 2010 menunjukkan bahwa terdapat 8 kelurahan yang tergenang banjir rob. Hal ini diperkuat dengan hasil penelitian Hardiyawan (2012), dimana ada 8 kelurahan yang tergenang banjir rob. Diantara 8 kelurahan tersebut, terdapat 2 kelurahan yang memiliki tingkat kerentanan banjir rob tertinggi dibandingkan dengan kelurahan lainnya. Kondisi tersebut menjadikan perlunya peningkatan kapasitas adaptasi masyarakat untuk menghadapi banjir rob.

Kapasitas adaptasi merupakan kemampuan sebuah sistem dalam menghadapi keterpaparan (Smit \& Pilifosova, 2003). Kapasitas adaptasi merupakan kemampuan sistem untuk menyesuaikan dengan perubahan iklim dengan mengurangi potensi kerusakan dengan memanfaatkan sumber daya sosial dan ekonomi, teknologi, akses informasi terkait dengan perubahan iklim dan kemampuan institusi dalam beradaptasi (Kumalasari, 2014). Clarvis dan Allan (2013) mengungkapkan bahwa kapasitas adaptasi menunjukkan upaya reaktif pemerintah dalam merespon perubahan iklim melalui jaringan, kerjasama, dan informasi. Adanya perubahan iklim akan berdampak pada kehidupan manusia dan kondisi lingkungan di sekitarnya. Oleh karena itu, diperlukan kapasitas adaptasi. Kapasitas adaptasi dalam menghadapi bencana seperti rob dapat dilakukan pada tingkat individu maupun komunitas hingga ke lingkup yang lebih luas, yaitu regional.

IPCC (2007) menyebutkan ada beberapa faktor penentu kapasitas adaptasi, yaitu sumber daya ekonomi, teknologi, informasi dan keterampilan, infrastruktur, tersedianya lembaga yang kuat dan terorganisasi dengan baik, pemerataan akses menuju sumber daya. Pada umumnya, kapasitas adaptasi merupakan kemampuan sistem dalam menghadapi dampak buruk akibat gangguan. Genangan banjir rob dapat menimbulkan kerusakan pada kondisi bangunan dan infrastruktur. Hal ini menunjukkan bahwa dibutuhkan kemampuan masyarakat dalam memperbaiki kondisi bangunan dan infrastruktur. Sebagaimana disebutkan oleh Dolan dan Walker (2004) bahwa salah satu penentu kapasitas adaptasi adalah adanya kemampuan pelaku adaptasi. Upaya yang dilakukan individu termasuk upaya untuk memperbaiki kondisi rumah. Handmer dan Dovers (1996) menyebutkan bahwa salah satu penentu kapasitas adaptasi adalah tersedianya sumber daya dan kemudahan akses ke sumber daya tersebut. Agar dapat mencapai sumber daya yang ada diperlukan jaringan infrastruktur. Satterthwaite, Hug, Pelling, Reid, dan Lankao (2007) menjelaskan bahwa kerusakan infrastruktur akan melemahkan kegiatan ekonomi karena diperlukan biaya untuk memperbaiki kerusakan infrastruktur.

IPCC (2007) menyebutkan bahwa sumber daya ekonomi merupakan salah satu penentu kapasitas adaptasi. Hal ini didukung oleh Williamson, Hesseln, dan Johnston 
(2010) yang menyatakan bahwa melalui sumber daya ekonomi ini para pembuat keputusan dapat mengidentifikasi biaya peluang dan cara yang paling efisien untuk mengatasi bencana. Kemampuan seseorang untuk menghindari bahaya atau untuk mengatasi dampak buruk bencana dipengaruhi oleh sumber daya individu/ rumah tangga yang meliputi pendapatan, dan pengetahuan (Satterthwaite et al., 2007). Smit dan Pilifosova (2003) membentuk kerangka kapasitas adaptasi yang berkaitan dengan perubahan iklim sebagaimana tergambarkan di Gambar 1.

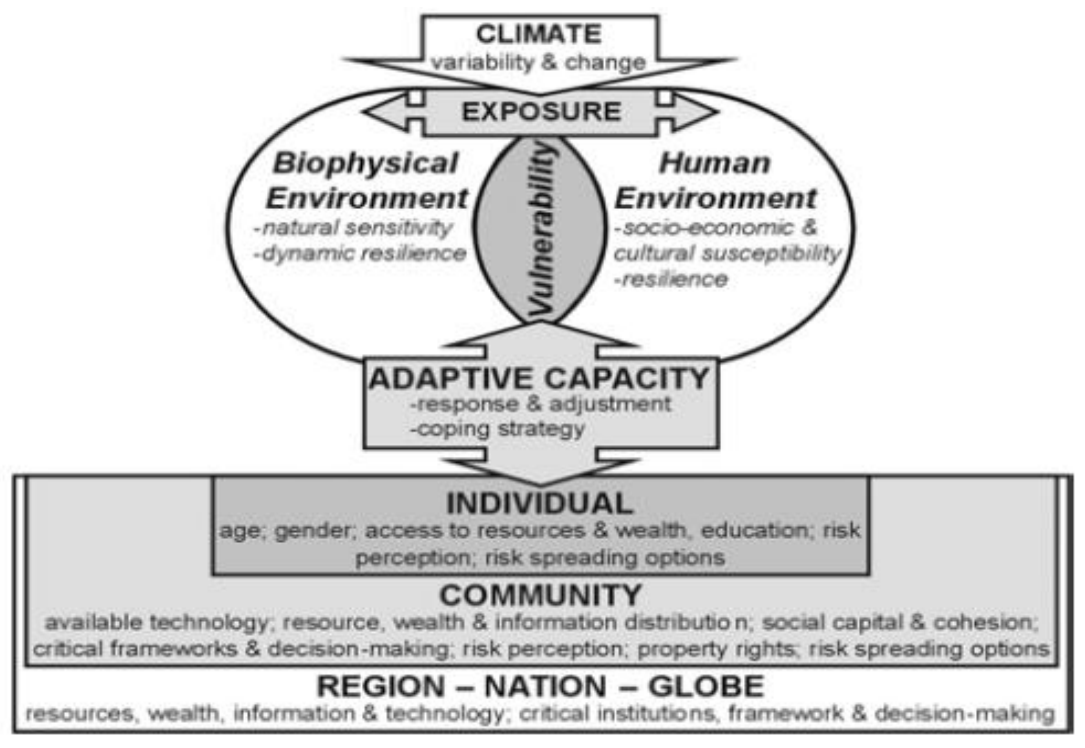

Sumber: Smit \& Pilifosova, 2003

\section{Gambar 1. Kerangka Kapasitas Adaptasi}

Pada saat ini, banyak strategi adaptasi perubahan iklim yang melibatkan teknologi, seperti sistem peringatan dini, langkah-langkah dalam pengendalian banjir, sistem peramalan musim dan lain sebagainya (Smit \& Pilifosova, 2003). Selain teknologi juga diperlukan modal atau kapasitas manusia. Yohe dan Tol (2002) serta Williamson et al. (2010) mengatakan bahwa salah satu modal dalam melakukan kapasitas adaptasi adalah modal manusia, meliputi kemampuan dan tingkat pendidikan. Selain itu, untuk meningkatkan kapasitas adaptasi juga diperlukan suatu organisasi masyarakat. Melalui organisasi masyarakat ini akan terjalin hubungan antara individu satu dengan lainnya untuk melakukan tindakan kolektif dalam mengatasi bencana (IPCC, 2007). Hal ini diperkuat oleh Yohe dan Tol (2002) bahwa struktur kelembagaan penting yang berperan dalam pengambilan keputusan berdasarkan kriteria. Lebih lanjut, Engle (2011) dan Dutra (2015) mengungkapkan bahwa penilaian kapasitas adaptasi dilihat dari kesiapan pemerintah, institusi dan manajemen dalam merespon perubahan iklim. Pemerintah dapat mengintervensi masyarakat untuk beradaptasi dan terhadap lingkungan dan sumber daya yang dimiliki mellaui upaya peningkatan modal sosial, jaringan, dan kepemimpinan (Folke, Hahn, Olsson, \& Norberg, 2005; Barnes et al., 2013). Gupta et al. (2010) juga menyatakan bahwa terdapat 6 dimensi untuk menilai kapasitas adaptasi, yaitu varietas, kapasitas pembelajaran, ketersediaan ruang untuk perubahan, kepemimpinan, ketersediaan sumber daya, dan peran pemerintah menentukan kemampuan kapasitas adaptasi masyarakat terhadap perubahan iklim baik di level lokal hingga nasional. 


\section{Kajian Kapasitas Adaptasi Masyarakat Pesisir Pekalongan terhadap Kerentanan Banjir Rob}

Banyak studi untuk menilai kapasitas adaptasi. Namun, hanya sedikit studi yang menilai kapasitas adaptasi secara komprehensif dari level individu hingga regional atau kota. Studi ini bertujuan untuk mengkaji kapasitas adaptasi masyarakat pesisir Pekalongan terhadap kerentanan banjir rob. Studi ini mencoba untuk membandingkan antara tingkat kapasitas adaptasi pada level individu/ rumah tangga, komunitas/ masyarakat dan kota. Penilaian kapasitas adaptasi dapat dilihat berdasarkan aspek fisik, sosial dan ekonomi. Lokasi studi difokuskan pada kedua kelurahan di Kota Pekalongan, yaitu Kelurahan Pabean dan Kelurahan Bandengan.

\section{Metode Penelitian}

Penelitian menggunakan metode kuantitatif dekriptif. Teknik pengumpulan data dibagi menjadi teknik pengumpulan data primer dan sekunder. Pengumpulan data primer dilakukan dengan cara melakukan observasi/ pengamatan, kuesioner dan wawancara. Sedangkan pengumpulan data sekunder dilakukan dengan cara telaah dokumen. Penilaian kapasitas adaptasi dilakukan dengan analisis skoring. Nilai yang paling tinggi yakni 3, menunjukkan tingkat kapasitas adaptasi yang tinggi. Sebaliknya, nilai yang rendah yakni 1 , menunjukkan tingkat kapasitas adaptasi yang rendah. Rentang skor yang digunakan dalam penelitian ini terdiri dari 3 kelas yaitu rendah, sedang, tinggi dengan masing-masing menggunakan 3 jenjang skor yaitu 1, 2 dan 3. Pemberian skor merupakan upaya untuk mengubah data interval dengan cara menjadikan skor tersebut memiliki kelas interval. Adapun penjelasan mengenai rentang skor dari seluruh kelas adalah sebagai berikut:

Klasifikasi nilai indikator

$\begin{array}{ll}\text { Nilai tertinggi } & =3 \\ \text { Nilai terendah } & =1 \\ \text { Klasifikasi kelas } & =3\end{array}$

Rentang skor $=($ Nilai Tertinggi - Nilai Terendah $) /$ Jumlah Klasifikasi Skor

Rentang skor dalam penelitian ini adalah sebagai berikut

Rentang $\quad=\frac{(3-1)}{3}=0,7$

Hasil perhitungan rentang dijabarkan ke dalam rentang skor serta klasifikasi sebagaimana terlihat di Tabel 1.

Tabel 1. Rentang Skor Tingkat Kapasitas Adaptasi

\begin{tabular}{ccc}
\hline Tingkat Kapasitas Adaptasi & Skor & Klasifikasi \\
\hline Rendah & 1 & $1-1,7$ \\
\hline Sedang & 2 & $1,8-2,3$ \\
\hline Tinggi & 3 & $2,4-3$ \\
\hline
\end{tabular}

Adapun sampel yang digunakan dalam penelitian tersebar di Kelurahan Pabean dan Bandengan dengan jumlah sampel seperti terjabarkan di Tabel 2. 
Tabel 2. Jumlah Sampel Penelitian di Tiap Kelurahan

\begin{tabular}{cccc}
\hline Kelurahan & RW & Jumlah KK & Jumlah Sampel (KK) \\
\hline \multirow{4}{*}{ Pabean } & 1 & 339 & 12 \\
& 2 & 332 & 11 \\
& 3 & 313 & 11 \\
& 4 & 287 & 10 \\
& 1 & 53 & 4 \\
Bandengan & 2 & 61 & 5 \\
& 3 & 303 & 10 \\
& 4 & 285 & 10 \\
Jumlah & 5 & 530 & 13 \\
& 6 & 253 & 9 \\
\hline
\end{tabular}

\section{Hasil dan Pembahasan}

\section{Tingkat Kapasitas Adaptasi Masyarakat}

Kapasitas adaptasi dalam menghadapi bencana seperti rob dapat dilakukan pada tingkat individu maupun komunitas hingga ke lingkup yang lebih luas yaitu regional (Smith \& Pilifosova, 2003). Pada penelitian ini kapasitas adaptasi dilakukan dengan cara pemberian skor pada aspek fisik, sosial dan ekonomi. Selain itu, penilaian juga dilakukan pada level individu/ household, komunitas, dan kota. Penentuan skor pada masing-masing aspek tiap level dilakukan dengan cara menjumlahkan seluruh variabel yang kemudian dibagi dengan jumlah responden.

\section{Aspek Fisik}

Masyarakat Kelurahan Pabean memiliki kemampuan dalam melakukan perbaikan jaringan infrastruktur yang lebih tinggi dibandingkan dengan Kelurahan Bandengan. Hal ini ditunjukkan oleh nilai kapasitas adaptasi pada level komunitas di Kelurahan Pabean lebih tinggi daripada Kelurahan Bandengan. Hasil analisis skoring menunjukkan bahwa pada Kelurahan Pabean memiliki nilai 1,9. Sedangkan Kelurahan Bandengan memiliki nilai 1,7. Masyarakat yang tergenang banjir rob dengan ketinggian $30 \mathrm{~cm}$ akan memiliki kemampuan meninggikan rumah lebih besar dibandingkan dengan masyarakat yang tergenang banjir rob $<30 \mathrm{~cm}$. Kapasitas adaptasi bila dilihat dari aspek fisik pada level kota memiliki nilai yang tinggi, yakni sebesar 3,0. Adanya teknologi yang berfungsi optimal dalam mengurangi genangan banjir rob menjadikan tingkat kapasitas adaptasi pada level kota tinggi.

Gambar 2 dan 3 merupakan grafik tingkat kapasitas adaptasi Kelurahan Pabean dan Kelurahan Bandengan. Gambar 2 menunjukkan tingkat kapasitas adaptasi masyarakat Kelurahan Pabedan dilihat dari aspek fisik. Gambar 3 menunjukkan tingkat kapasitas adaptasi masyarakat Kelurahan Bandengan. Berdasarkan grafik di Gambar 2 dan 3, terlihat bahwa kapasitas adaptasi masyarakat pada level individu pada kedua kelurahan tersebut memiliki tingkat yang rendah dibandingkan dengan level komunitas dan kota. Hal ini ditunjukkan dengan nilai skoring yang ada mencapai 1,5, sedangkan pada level komunitas nilai skoring yang ada mencapai 1,9 dan pada level kota nilai skoringnya mencapai 3,0. Kemampuan masyarakat dalam menghadapi banjir rob yang berupa kemampuan dalam memperbaiki kondisi rumah dianggap kurang mampu menghadapi rob yang terjadi. 


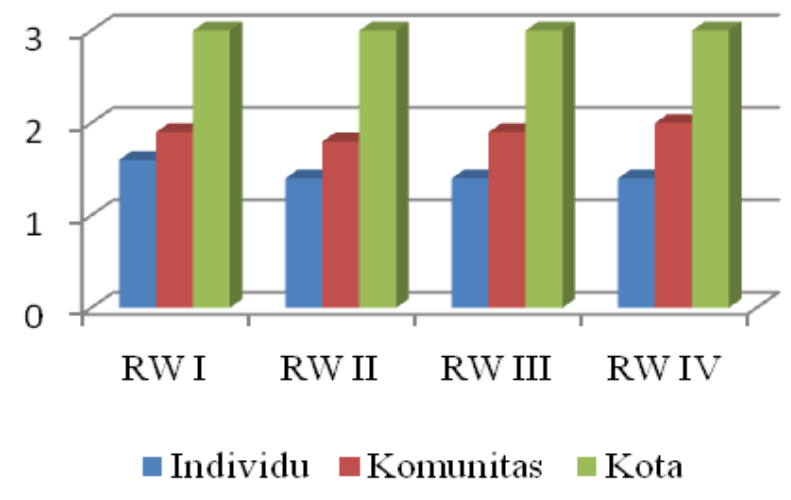

Gambar 2. Tingkat Kapasitas Adaptasi Masyarakat Kelurahan Pabean Ditinjau dari Aspek Fisik

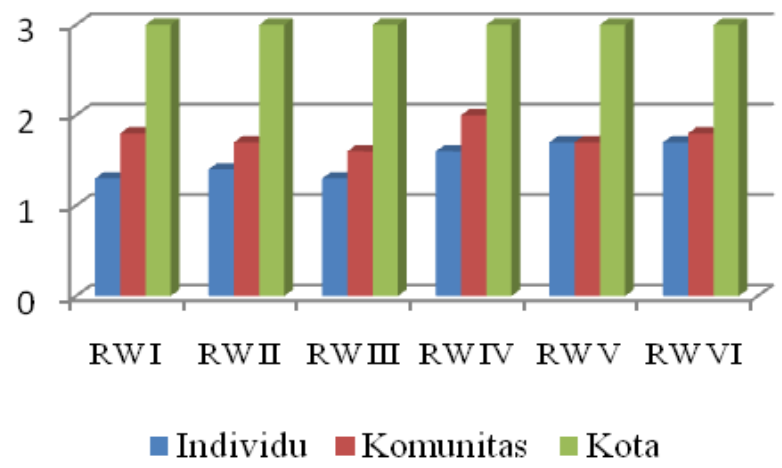

Gambar 3. Tingkat Kapasitas Adaptasi Masyarakat Kelurahan Bandengan Ditinjau dari Aspek Fisik

\section{Aspek Sosial}

Tingkat pendidikan mempengaruhi kemampuan masyarakat dalam menghadapi banjir rob. Hal ini dikarenakan tinggi rendahnya pendidikan masyarakat mempengaruhi jenis dan tingkat pendapatan yang diperoleh masyarakat. Masyarakat Kelurahan Pabean dan Kelurahan Bandengan cenderung memiliki tingkat pendidikan yang rendah, mayoritas masyarakat berpendidikan SD sehingga hal ini menjadikan tingkat kapasitas adaptasi pada kedua kelurahan ini adalah rendah. Adapun nilai skoring yang menunjukkan rendahnya tingkat kapasitas adaptasi masyarakat pada level individu ini adalah 1,4 pada Kelurahan Pabean dan 1,2 pada Kelurahan Bandengan.

Tingkat kapasitas adaptasi pada kedua kelurahan ini sedang bila ditinjau dari aspek sosial pada level komunitas. Nilai skoring yang menunjukkan tingkat kapasitas adaptasi masyarakat yang sedang ini ditunjukkan dengan nilai 2,0. Selain itu, tingkat kapasitas adaptasi ini juga dikarenakan pada kedua kelurahan ini terdapat organisasi masyarakat namun tidak terdapat kegiatan dalam mengurangi genangan banjir rob pada organisasi masyarakat tersebut. Adapun nilai skoring pada level kota mencapai 3,0. Pada level kota tingkat kapasitas adaptasi pada kedua kelurahan ini memiliki tingkat kapasitas adaptasi yang tinggi. Hal ini ditunjukkan dengan tersedianya kelembagaan yang berperan aktif dalam mengurangi genangan banjir rob. 
Gambar 4 menunjukkan tingkat kapasitas adaptasi masyarakat Kelurahan Pabean dilihat dari aspek sosial. Sedangkan gambar 5 menunjukkan tingkat kapasitas adaptasi masyarakat Kelurahan Bandengan dari aspek sosial. Berdasarkan kedua Gambar 4 dan Gambar 5 tersebut, dapat diketahui bahwa pada Kelurahan Pabean dan Kelurahan Bandengan memiliki tingkat kapasitas adaptasi level kota yang lebih tinggi daripada level individu dan komunitas. Hal ini menunjukkan bahwa pada level kota, masyarakat memiliki kemampuan yang tinggi dalam menghadapi genangan banjir rob bila ditinjau dari aspek sosial. Sedangkan pada level individu tingkat kapasitas adaptasi masyarakat lebih rendah jika dibandingkan dengan level komunitas dan kota.

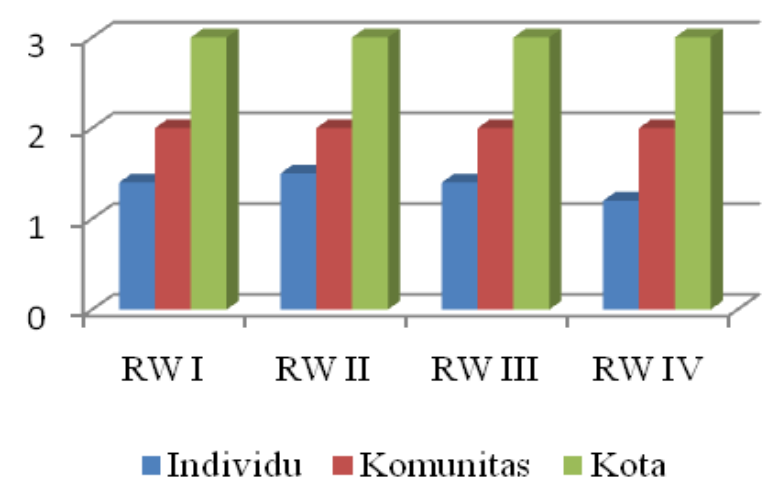

Gambar 4. Tingkat Kapasitas Adaptasi Masyarakat Kelurahan Pabean Ditinjau dari Aspek Sosial

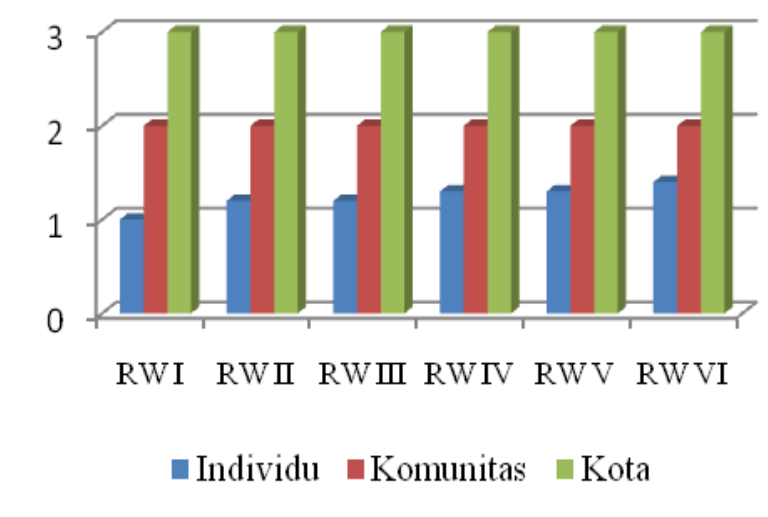

Gambar 5. Tingkat Kapasitas Adaptasi Masyarakat Kelurahan Bandengan Ditinjau dari Aspek Sosial

\section{Aspek Ekonomi}

Pada Kelurahan Pabean dan Kelurahan Bandengan memiliki tingkat kapasitas adaptasi yang sedang bila ditinjau dari aspek ekonomi secara keseluruhan. Hal ini berdasarkan hasil analisis skoring yang menunjukkan nilai sebesar 2,1. Pada level individu, tingkat kapasitas adaptasi pada kedua kelurahan ini rendah. Rendahnya tingkat kapasitas adaptasi ini ditunjukkan oleh nilai skoring yang ada, yakni sebesar 1,3. Selain itu, rendahnya tingkat kapasitas adaptasi ini juga ditunjukkan dengan rendahnya tingkat pendapatan masyarakat. 
Masyarakat kedua kelurahan ini mampu mengumpulkan dana yang berasal dari pemerintah tanpa melibatkan dana dari masyarakat, dimana dana yang dikumpulkan masyarakat ini digunakan untuk memperbaiki jaringan infrastruktur. Hal ini menjadikan tingginya tingkat kapasitas adaptasi masyarakat bila ditinjau dari aspek ekonomi pada level komunitas. Berdasarkan analisis skoring menunjukkan bahwa tingkat kapasitas adaptasi pada level komunitas mencapai 3,0. Sedangkan pada level kota, kedua kelurahan ini memiliki tingkat kapasitas adaptasi yang sedang. Hal ini ditunjukkan oleh nilai skoring yang ada, yakni sebesar 2,0.

Pada level kota, tingkat kapasitas adaptasi dipengaruhi oleh bantuan yang diberikan pemerintah dan peningkatan ekonomi yang dilakukan pemerintah untuk mengatasi genangan banjir rob. Peningkatan ekonomi yang dilakukan pemerintah berupa pelatihan keterampilan masyarakat.

Gambar 6 menunjukkan tingkat kapasitas adaptasi masyarakat Kelurahan Pabedan dilihat dari aspek ekonomi. Sedangkan Gambar 7 menunjukkan tingkat kapasitas adaptasi masyarakat Kelurahan Bandengan dari aspek ekonomi. Berdasarkan grafik tersebut di atas dapat diketahui bahwa, tingkat kapasitas adaptasi pada level komunitas memiliki tingkat yang paling tinggi daripada level individu dan kota. Hal ini menunjukkan bahwa masyarakat memiliki kemampuan yang tinggi dalam mengumpulkan dana yang dapat digunakan untuk melakukan perbaikan jaringan infrastruktur. Sedangkan pada level kota, tingkat kapasitas adaptasinya sedang dan pada level individu, tingkat kapasitas adaptasi masyarakat adalah rendah. Peta jenis tipologi kapasitas adaptasi masyarakat di Kelurahan Pabean dan Bandengan tergambarkan di Gambar 8 untuk level individu, Gambar 9 untuk level komunitas dan Gambar 10 untuk level kota.

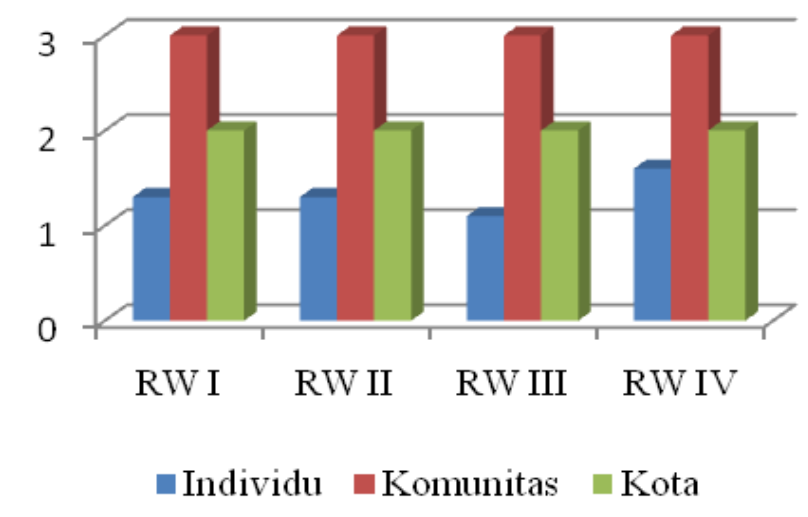

Gambar 6. Tingkat Kapasitas Adaptasi Masyarakat Kelurahan Pabean Ditinjau dari Aspek Ekonomi 


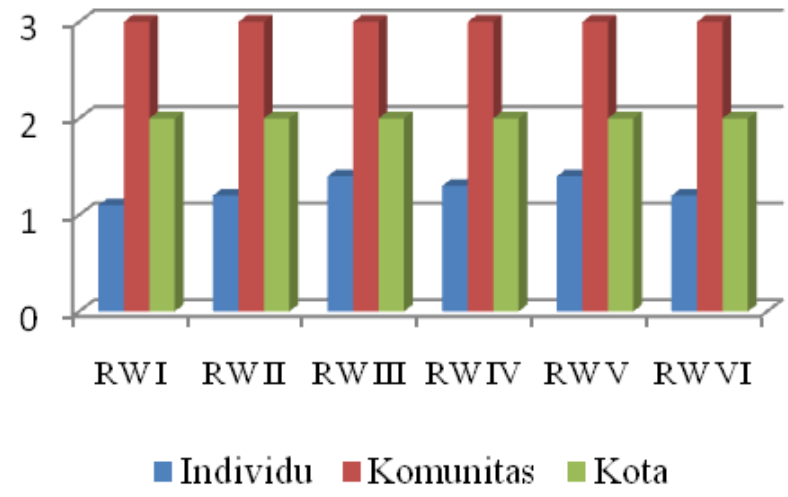

\section{Gambar 7. Tingkat Kapasitas Adaptasi Masyarakat Kelurahan Bandengan Ditinjau dari Aspek Ekonomi}

Kapasitas adaptasi lebih didominasi oleh kemampuan masyarakat dalam memperbaiki rumah. Tingkat pendidikan dan tingkat pendapatan yang rendah menjadikan kemampuan masyarakat rendah dalam aspek sosial dan ekonomi

Tingkat kapasitas adaptasi lebih didominasi pada aspek sosial, hal ini ditunjukkan oleh tingkat pendidikan masyarakat yang cenderung tinggi, tingkat pendidikan yang tinggi ini akan mempengaruhi tingkat pengetahuan masyarakat terhadap banjir rob. Sedangkan pada aspek fisik dan ekonomi memiliki nilai yang rendah

Tingkat kapasitas adaptasi pada aspek ekonomi memiliki nilai yang lebih tinggi dibandingkan aspek fisik dan sosial. $\mathrm{Hal}$ ini menunjukkan masyarakat memiliki kemampuan yang cukup dalam mengatasi genangan banjir rob bila ditinjau dari aspek ekonomi.

Tingkat kapasitas adaptasi baik pada aspek fisik, sosial dan ekonomi memiliki nilai yang rendah.
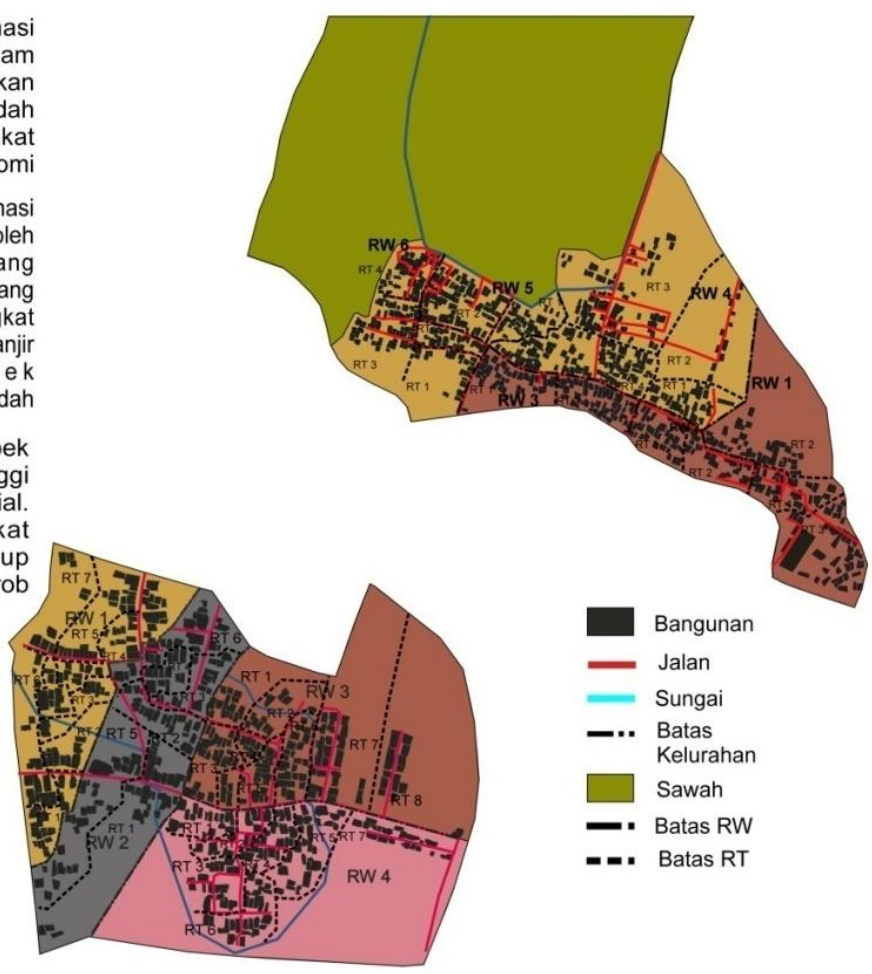

Gambar 8. Kapasitas Adaptasi Masyarakat Kelurahan Pabean dan Kelurahan Bandengan pada Level Individu 
Kapasitas adaptasi lebih didominasi pada aspek ekonomi, hal ini ditandai oleh kemampuan masyarakat dalam memperoleh sumber dana yang berasal dari pemerintah. Sedangkan pada aspek fisik dan sosial memiliki tingkat yang sedang.

Masyarakat memiliki kemampuan yang rendah dalam melakukan perbaikan infrastruktur, sehingga tingkat kapasitas adaptasi masyarakat rendah bila ditinjau dari aspek fisik. Bila ditinjau dari aspek sosial, tingkat kapasitas adaptasi yang ada sedang. Pada aspek ekonomi, nilai kapasitas adaptasi masyarakat adalah tinggi.

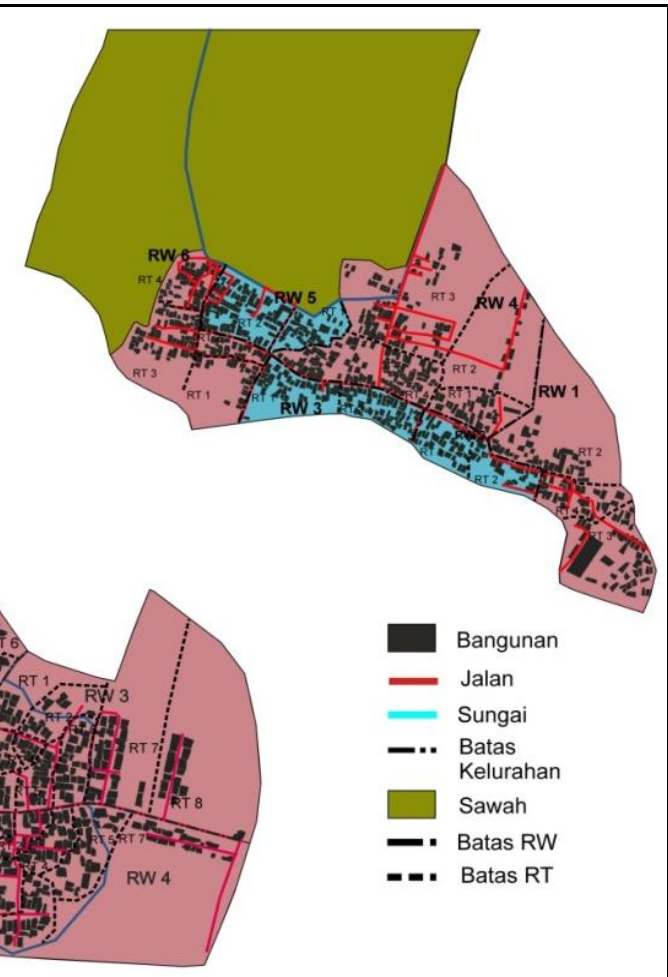

\section{Gambar 9. Kapasitas Adaptasi Masyarakat Kelurahan Pabean dan Kelurahan Bandengan pada Level Komunitas}

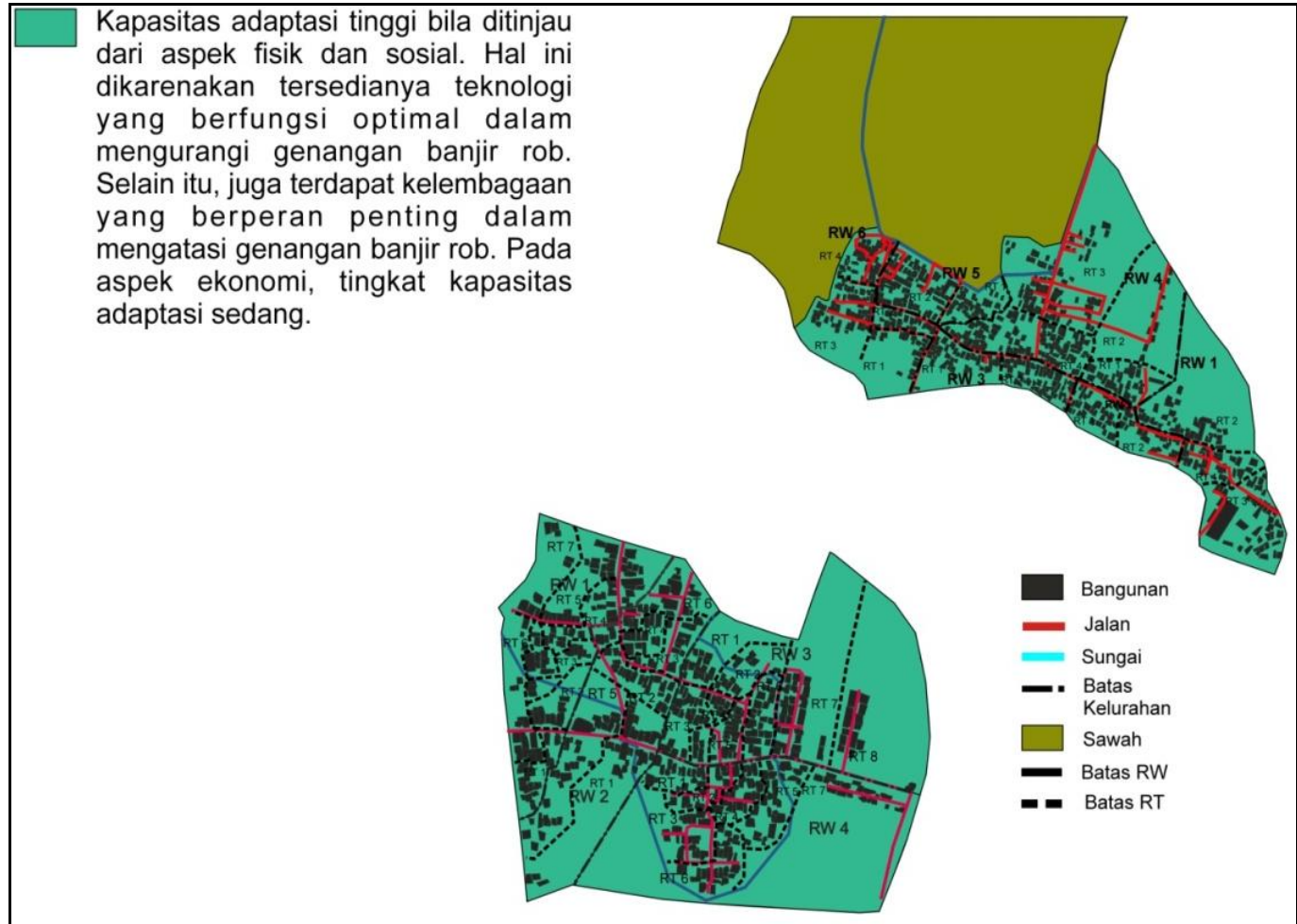

Gambar 10. Kapasitas Adaptasi Masyarakat Kelurahan Pabean dan Kelurahan Bandengan pada Level Kota 


\section{Hubungan Kapasitas Adaptasi Masyarakat terhadap Kerentanan Banjir Rob}

Bila ditinjau dari aspek fisik, masyarakat yang tergenang banjir rob dengan tinggi genangan $30 \mathrm{~cm}$ cenderung memiliki kemampuan yang tinggi dalam melakukan perbaikan rumah dan infrastruktur dibandingkan dengan masyarakat yang tergenang banjir rob $<30$ $\mathrm{cm}$. Pada Kelurahan Pabean dan Kelurahan Bandengan memiliki tingkat kapasitas adaptasi yang tinggi pada level kota. Peta hubungan kapasitas adaptasi ditinjau dari aspek fisik tergambarkan di Gambar 11.

Mayoritas masyarakat Kelurahan Pabean dan Kelurahan Bandengan memiliki tingkat pendidikan yang rendah. Hal ini mempengaruhi jenis pekerjaan dan tingkat pendapatan yang diperoleh masyarakat serta tingkat kapasitas adaptasi masyarakat. Pada level kota, tingkat kapasitas adaptasi pada kedua kelurahan memiliki tingkat yang tinggi. Kondisi ini dikarenakan tersedianya kelembagaan yang berperan penting dalam mengurangi genangan banjir rob. Peran dan kemampuan organisasi menentukan kapasitas adaptasi (Dutra, 2015; Engle, 2011). Peta hubungan kapasitas adaptasi ditinjau dari aspek sosial tergambarkan di Gambar 12.

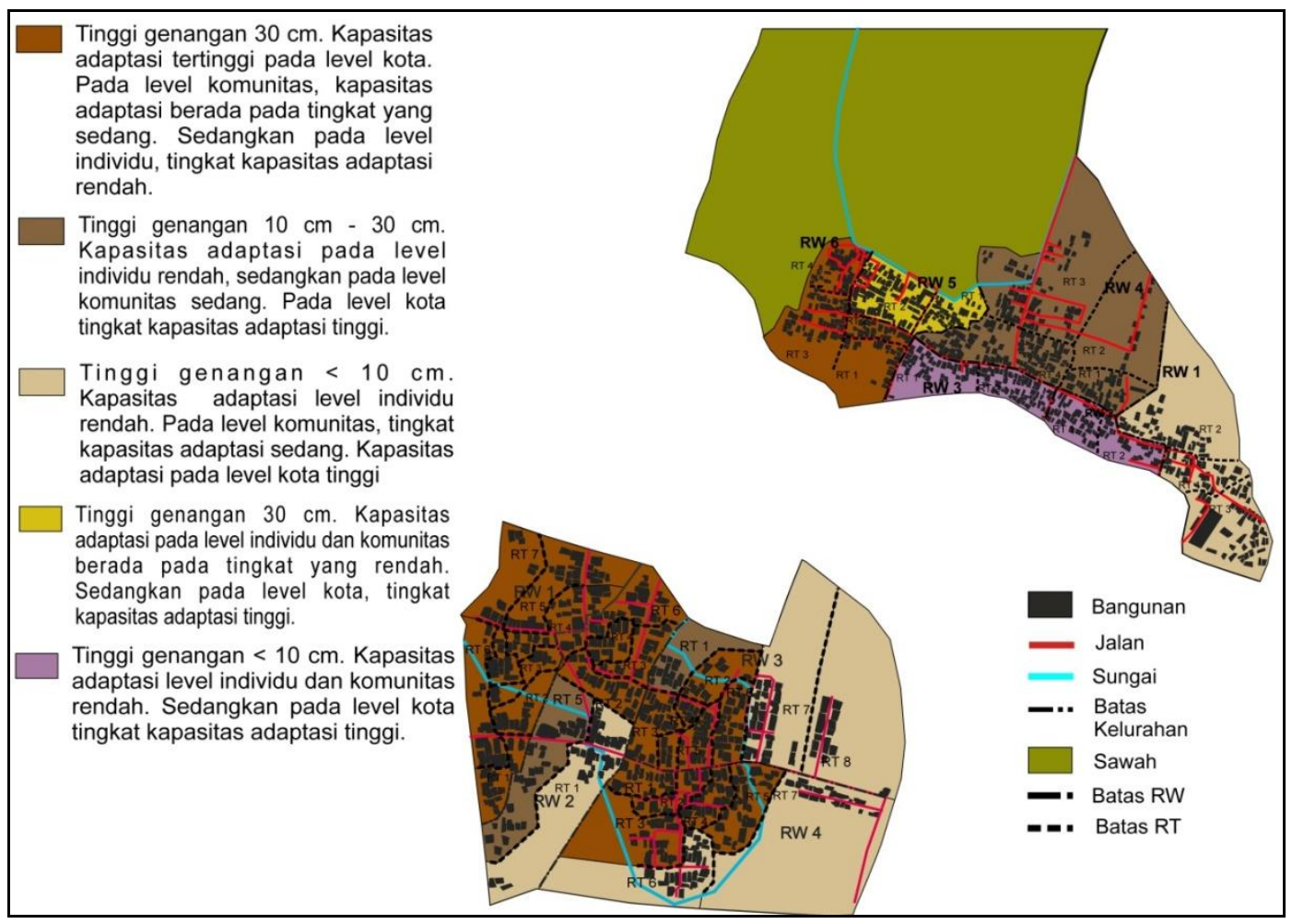

\section{Gambar 11. Peta Hubungan Kapasitas Adaptasi Ditinjau dari Aspek Fisik terhadap Kerentanan Banjir Rob}




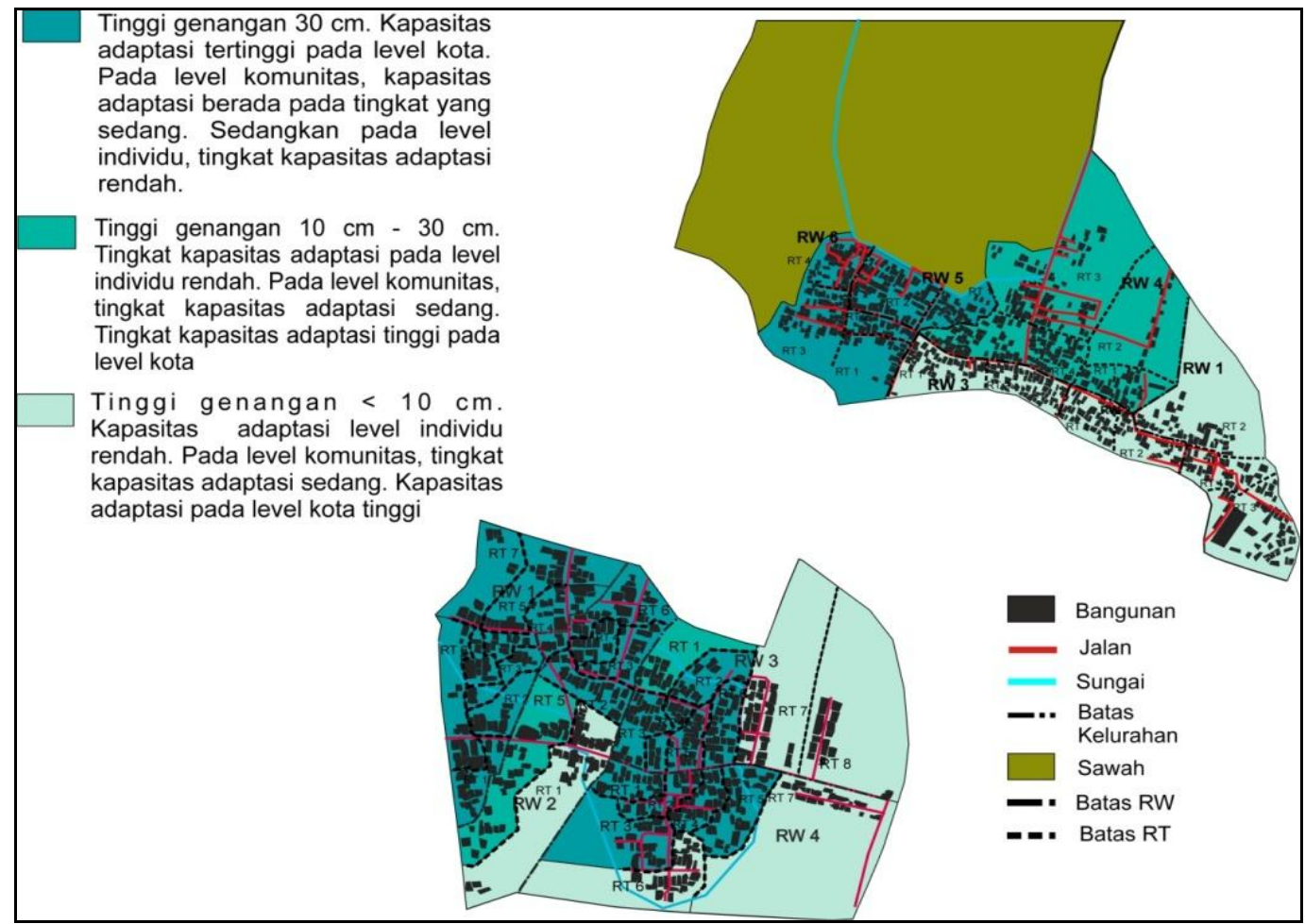

\section{Gambar 12. Peta Hubungan Kapasitas Adaptasi Ditinjau dari Aspek Sosial terhadap Kerentanan Banjir Rob}

Pada level komunitas, tingkat kapasitas adaptasi Kelurahan Pabean dan Kelurahan Bandengan memiliki nilai yang tinggi bila ditinjau dari aspek ekonomi. Hal ini dikarenakan masyarakat mampu mengumpulkan dana yang berasal dari pemerintah, dimana dana yang diperoleh masyarakat digunakan untuk melakukan perbaikan jaringan infrastruktur. Sedangkan pada level individu, tingkat kapasitas adaptasi pada kedua kelurahan ini memiliki nilai yang rendah, hal ini dikarenakan rendahnya tingkat pendapatan yang diperoleh masyarakat. Rendahnya tingkat pendapatan masyarakat ini mempengaruhi tingkat kapasitas adaptasi masyarakat. Hal ini sejalan dengan pendapat IPCC (2007) dan Williamson et al. (2010) bahwa ketersediaan sumber daya ekonomi menentukan kapasitas adaptasi. Peta hubungan kapasitas adaptasi ditinjau dari aspek ekonomi tergambarkan di Gambar 13.

Temuan-temuan tersebut mengindikasikan bahwa kapasitas adaptasi ditentukan oleh kemampuan masing-masing pelaku adaptasi yang dilihat dari kepemilikan modal/ sumber daya, kemudahan akses ke sumber daya tersebut, dan ketersediaan sistem kelembaagaan. Semakin tinggi levelnya, seperti pada level komunitas dan level kota, akan memiliki kapasitas adaptasi yang lebih baik daripada level individu sejalan dengan sumber daya dan kemampuan yang dimiliki. Hal ini sesuai dengan temuan Handmer dan Dovers (1996), Dolan dan Walker (2004), serta IPCC (2007). 


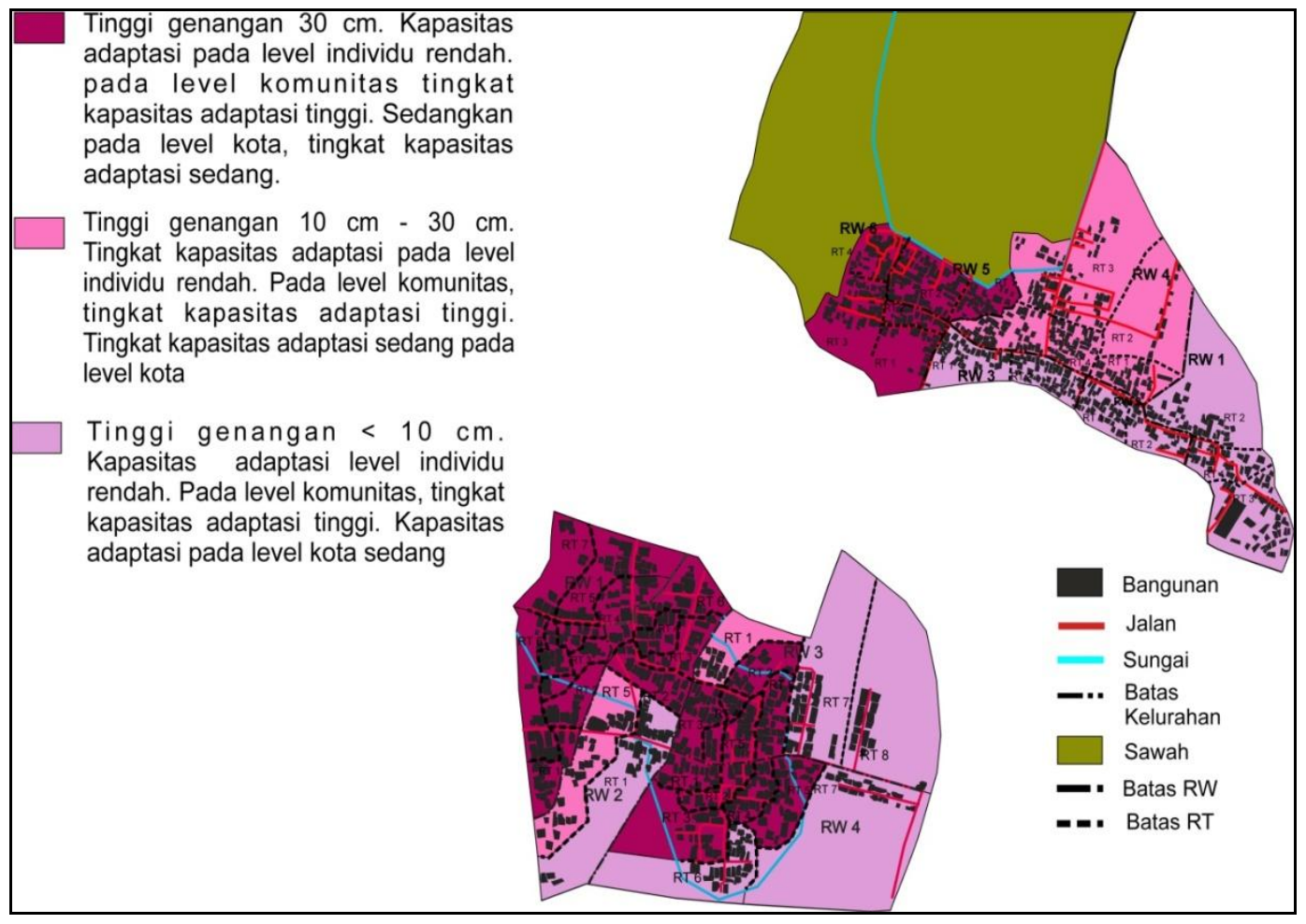

\section{Gambar 13. Peta Hubungan Kapasitas Adaptasi Ditinjau dari Aspek Ekonomi terhadap Kerentanan Banjir Rob}

\section{Kesimpulan}

Komponen kapasitas adaptasi masyarakat terdiri atas kemampuan memperbaiki rumah, kemampuan memperbaiki infrastruktur, ketersediaan teknologi, ketersediaan sumber daya manusia, keberadaan organisasi, ketersediaan kelembagaan, kemampuan ekonomi, sumber dana yang digunakan untuk menangani banjir rob, ketersediaan modal ekonomi. Pada level kota, tingkat kapasitas adaptasi pada Kelurahan Pabean dan Kelurahan Bandengan memiliki tingkat yang tinggi, yakni sebesar 3,0. Hal ini ditunjukkan dengan tersedianya teknologi yang berfungsi optimal dalam mengurangi genangan banjir rob. Sementara itu, jika ditinjau pada aspek sosial, pada level individu Kelurahan Pabean dan Bandengan memiliki level rendah, sedangkan pada level komunitas memiliki kapasitas adaptasi sedang karena memiliki kelembagaan yang berperan cukup baik dalam mengurangi bahaya banjir dan rob. Jika ditinjau pada aspek ekonomi, Kelurahan Pabean dan Bandengan memiliki kapasitas adaptasi yang rendah pada level individu karena rendahnya tingkat pendapatan masyarakat, pada level komunitas tingkat kapasitas adaptasi masyarakat berlevel tinggi karena tingginya kemampuan masyarakat dalam mengumpulkan sumber dana dari pemerintah yang digunakan dalam memperbaiki jaringan infrastruktur, dan pada level kota tingkat kapasitas adaptasi berlevel sedang.

\section{Daftar Pustaka}

Barnes, J., Dove, M. Lahsen, M., Mathews, A., Mcelwee, P., Mcintosh, R., . . Yager, K. (2013). Contribution of anthropology to the study of climate change. Nature Climate Change, 3, 541-544. doi:10.1038/nclimate1775. 


\section{Kajian Kapasitas Adaptasi Masyarakat Pesisir Pekalongan terhadap Kerentanan Banjir Rob}

Clarvis, M. H., \& Allan, A. (2013). Adaptive capacity in a Chilean context: A questionable model for Latin America. Environmental Science \& Policy, 43, 78-90. doi:10.1016/j.envsci.2013.10.014.

Dolan, A. H., \& Walker, I. J. (2004). Understanding vulnerability of coastal communities to climate change related risks. Journal of Coastal Research, 39, 1316-1323.

Dutra, L. X. C., Bustamante, R. H., Sporne, I., van Putten, I., Dichmont, C. M., Ligtermoet, E., . . Deng, R. A. (2015). Organizational drivers that strengthen adaptive capacity in the coastal zone in Australia. Ocean \& Coastal Management, 109, 64-76. doi:10.1016/j.ocecoaman.2015.02.008.

Engle, N. L. (2011). Adaptive capacity and its assessment. Global Environmental Change, 21(2), 647-656. doi:10.1016/j.gloenvcha.2011.01.019.

Folke, C., Hahn, T., Olsson, P., \& Norberg, J. (2005). Adaptive governance of social-ecological systems. Annual Review of Environment and Resources, 30, 441-473. doi:10.1146/annurev.energy.30.050504.144511.

Gupta, J., Termeer, C., Klostermann, J., Meijerink, S., van den Brink, M., Jong, P., . . Bergsma, E. (2010). The adaptive capacity wheel: A method to assess the inherent characteristics of institutions to enable the adaptive capacity of society. Environmental Science \& Policy, 13(6), 459-471. doi:10.1016/j.envsci.2010.05.006.

Handmer, J. W., \& Dovers, S. (1996). A typology of resilience: Rethinking institutions for sustainable development. Industrial and Environmental Crisis Quarterly, 9(4), 482-511. doi:10.1177/108602669600900403.

Hardiyawan, M. (2012). Kerentanan wilayah terhadap banjir rob di pesisir Kota Pekalongan. (Tugas Akhir Departemen Geografi, Fakultas Matematika dan Ilmu Pengetahuan Alam, Universitas Indonesia, Indonesia). Retrieved from http://lib.ui.ac.id/file?file=digital/20294641-S1707Mukti\%20Hardiyawan.pdf.

IPCC. (2007). "Climate change 2007: Impacts, adaptation and vulnerability." A Special Report of Working Group II of the Inter-governmental Pannel on Climate Change. Cambridge, UK: Cambridge University Press.

Kumalasari, N. R. (2014). Kapasitas adaptasi terhadap kerentanan perubahan iklim di Tambak Lorok, Kelurahan Tanjung Mas Semarang. Jurnal Pembangunan Wilayah dan Kota, 10(4), 476-487.

Noson, L. (2002, September). Hazard mapping and risk assessment. Paper presented at The Regional Workshop on Best in Disaster Mitigation, Bali, Indonesia.

Satterthwaite, D., Hug, S., Pelling, M., Reid, H., \& Lankao, P. R. (2007). Adapting to climate change in urban areas: The possibilities and constraints in low-and middle-income nations. Retrieved from http://pubs.iied.org/pdfs/10549IIED.pdf.

Smit, B., \& Pilifosova, O. (2003). From adaptation to adaptive capacity and vulnerability reduction. In: J. B. Smith, R. J. T. Klein, \& S. Huq (Eds.), Climate Change, Adaptive Capacity and Development. London: Imperial College Press, London.

Williamson, T., Hesseln, H., \& Johnston, M. (2010). Adaptive capacity deficits and adaptive capacity of economic systems in climate change vulnerability assessment. Forest Policy and Economics, 15, 160166. doi:10.1016/j.forpol.2010.04.003.

Yohe, G., \& Tol, R. S. J. (2002). Indicators for social and economic coping capacity-moving toward a working definition of adaptive capacity. Global Environmental Change, 12(1), 25-40. doi:10.1016/S09593780(01)00026-7. 